\title{
Penggunaan Strategi Aliansi Pada Perusahaan Multinasional \\ Dengan Studi Kasus Industri Alat-Alat Medis DI Indonesia
}

\author{
Mochamad Fernaldi Subiakto
}

\section{Strategi Aliansi}

Strategi aliansi adalah kerjasama antara dua atau lebih perusahaan atau unit bisnis yang bekerjasama untuk mencapai tujuan yang signifikan secara strategis yang saling menguntungkan. Ada lima jenis strategi aliansi yaitu wholly owned subsidiaries, joint venture, licence agreement, subcontracting and outsourcing. Setiap strategi tersebut memiliki kelebihan dan kelemahan sebagai berikut :

1. Wholly Owned Subsidiaries : Ada beberapa kelebihan pada strategi ini yaitu strategi masuk yang lebih cepat, pengalaman manajemen sudah terbentuk dan nama merek dan reputasi sudah terbentuk. Sedangkan kelemahan dari strategi ini adalah masalah kordinasi dan masalah integrasi dengan operasi yang ada. Pada dasarnya pemilihan strategi ini didasari pada faktor spesifik negara dan faktor spesifik perusahaan (Moon \& Kwon, 2010).

2. Joint Venture : Kelebihan dari strategi ini adalah mitra lebih memahami akan keadaan yang ada di lingkungan, dimana perusahaan joint venture itu didirikan dan sekutu atau mitra lokal mempunyai teknologi yang cocok dengan kondisi lingkungan setempat sedangkan kelemahan dari startegi ini adalah adanya harga transfer produk atau komponen akan menimbulkan konflik kepentingan antara kedua belah pihak. Pada saat terjadi pasar gagal, transaksi pasar tidak pasti dan informasi akan dibagikan secara asimetris antara pihak-pihak yang berdagang, dalam situasi ini, Wholly Owned Subsidiaries lebih baik dari pada joint venture (Moon \& Kwon, 2010).

3. Licence Agreement : Kelebihan dari strategi ini adalah perusahaan membuat kontrak pembelian dengan distributor lokal untuk barang atau jasa pada waktu tertentu untuk memotong biaya dan kerugian persediaan terkait dengan ketidakpastian permintaan (Wang, Li, Liang, Huang, \& Ashley, 2015). Dari sudut pandang pelanggan, kontrak pembelian sangat penting untuk meningkatkan integrasi layanan strategis, yang membawa kecenderungan untuk menciptakan aliansi strategis dengan suppliers lokal. 
4. Subcontracting dan Outsourcing : Kelebihan dari startegi ini adalah subkontrak dapat mengarahkan subkontraktor untuk fokus pada pengetahuan yang sudah dikembangkan oleh klien. Hal ini menunjukkan bahwa dengan subkontrak, sebuah perusahaan akan terlibat dalam "reconfiguring existing knowledge" untuk menghasilkan hasil tambahan sebagai lawan dari "encompassing new knowledge" yang dapat menghasilkan hasil yang radikal (Oke \& Onuegbuzie, 2013). Tetapi kelemahan dari strategi ini adalah bahwa subkontrak dapat membatasi perolehan pengetahuan perusahaan pada apa yang berkaitan dengan pekerjaan tertentu yang sedang disubkontrakkan. Akibatnya, perusahaan subkontraktor mungkin tidak memiliki kesempatan untuk mengeksplorasi pengetahuan baru yang bersifat transformasional dan dapat mendorong inovasi (Oke \& Onuegbuzie, 2013).

\section{Studi Kasus Industri Alat-Alat Medis di Indonesia}

Studi yang dilakukan oleh Pratono dan Ratih (2019) mengidentifikasi jenis penetrasi pasar dan aliansi strategis dalam industri alat kesehatan di Indonesia adalah wholly subsidiary with the licence agreement, purchasing contract, noncontractual collaboration, non-equity contractual collaboration and equity alliance. Tetapi dari penelitian yang dilakukan Pratono dan Ratih (2019) menyimpulkan strategi yang lebih sering dipakai adalah dengan melakukan kontrak pembelian, noncontractual collaboration, non-equity collaboration and equity alliance.

\section{Referensi}

Moon, H.-C., \& Kwon, D.-B. (2010). Entry Mode Choice between Wholly-Owned Subsidiary and Joint Venture: A Case Study of the Automotive Industry in India. International Journal of Performability Engineering, 605-614.

Oke, A., \& Onuegbuzie, H. (2013). Outsourcing, subcontracting-in and radical innovativeness: The moderating effect of manufacturing strategy. Journal of Manufacturing Technology Management, 24(4), 511-535.

Pratono, A. H., \& Ratih, R. V. (2019). International Alliance Strategies: A Case Study of the Indonesian Medical Device Industry. Globalization and Development. Contributions to Management Science, 381-400. doi:https://doi.org/10.1007/978-3-030-11766-5_15

Wang, X., Li, F., Liang, L., Huang, Z., \& Ashley, A. (2015). Pre-purchasing with option contract and coordination in a relief supply chain. International Journal of Production Economics, 167, 170-176. 